\title{
Histopathologic Changes in Liver and Kidney Tissues from Male Sprague Dawley Rats Treated with Rhaphidophora Decursiva (Roxb.) Schott Extract
}

Siti Suriani Arsad ${ }^{1}$, Norhaizan Mohd Esa ${ }^{1 *}$ and Hazilawati Hamzah ${ }^{2}$

${ }^{1}$ Department of Nutrition and Dietetics, Faculty of Medicine and Health Sciences, Universiti Putra Malaysia, 43400 Serdang, Selangor, Malaysia

${ }^{2}$ Department of Pathology and Microbiology, Faculty of Veterinary Medicine, Universiti Putra Malaysia, 43400 Serdang, Selangor, Malaysia

\begin{abstract}
Rhaphidophora decursiva (Roxb.) Schott is commonly used to treat colon cancer among Chinese community in Malaysia. This study aims to evaluate histopathologic changes in liver and kidney tissues after treated with $R$. decursiva extract in male Sprague Dawley rats. The rats were divided into 4 groups consisting of 6 rats per group for each acute, subacute and subchronic toxicity evaluations, with a total of 72 rats. All control groups received distilled water (vehicle). For subacute toxicity, the 3 treatment groups received a daily oral dose of the plant extract at 70 , 140 or $210 \mathrm{mg} / \mathrm{kg}$ for 28 days. As no lethality was observed in subacute toxicity study, similar doses were used for the 3 treatment groups in 90-day subchronic toxicity. Histological examination of liver revealed some abnormal but not significant morphology characteristics. For acute toxicity, liver tissues in group treated with 2100 and 3500 mg/ $\mathrm{kg}$ extracts showed presence of activated kupffer cells, sinusoidal dilatation and cytoplasmic vacuolation, same as group treated with 140 and $210 \mathrm{mg} / \mathrm{kg}$ extracts for both subacute and subchronic toxicity. However, group treated with $140 \mathrm{mg} / \mathrm{kg}$ extract in subchronic toxicity just showed the presence of cytoplasmic vacuolation. Similarly, no significant abnormal histopathological changes were observed in kidneys tissue for all toxicity studies. The presence of granular cast were noticed in group treated with 2100 and $3500 \mathrm{mg} / \mathrm{kg}$ extracts for acute toxicity, however, cellular and protein cast only occurred in group treated with $3500 \mathrm{mg} / \mathrm{kg}$ extracts. For subacute and subchronic toxicity, granular cast can be observed in group treated with $210 \mathrm{mg} / \mathrm{kg}$ extract. Also, cellular can be seen in group treated with $210 \mathrm{mg} / \mathrm{kg}$ extract for subacute toxicity. In conclusion, the treatment of $R$. decursiva extracts did not show any significant toxicological changes as observed by histopathological examination in the kidney and liver tissues for all toxicity studies.
\end{abstract}

Keywords: Rhaphidophora decursiva (Roxb.) Schott extract; Liver; Kidney; Histopathologic changes

Abbreviations: ACUC: Animal Care Use Committee; CC: Cellular cast; CV: Central vein; CPV: Cytoplasmic vacuolation; GC: Granular cast; H\&E: Hematoxylin \& Eosin; KC: kupffer cell; OECD: Organization for Economic Cooperation and Development; PC: Protein cast; SD: Sinusoidal dilatation; SEM: Standard error mean; UPM: Universiti Putra Malaysia

\section{Introduction}

'Herbalogy' or herbalism can be described as any type of medication that uses plant products for the treatment process [1]. Herbal medications consist of herbs, herbal preparations, herbal materials and finished herbal products. Different herbs and also different parts of plants may contain active ingredients with different medicinal properties which can affect certain diseases. Majority of the public considered herbal medicine as having low side effects and can improve the consequences of conventional agents or be a substitute treatment [2].

McCann [3] reported that herbs have significance value in current day biomedical antidotes. In a quarter of biomedical medications regularly prescribed nowadays, at least one active ingredient comes from plants and the rest of the substances are chemically produced in laboratories. Joshi and Kaul [4] further added that traditional herbal medicines are gaining popularity globally and these products purchases have raised significantly. This is due to the fact that a lot of researches have reported that essences from some herbal medicines or blend have an anticancer potential in vitro or in vivo.

Rhaphidophora decursiva (Roxb.) Schott, known by various vernacular names such as 'climbing dragon' or 'pha shu long' is one of the herbs that have been used widely in the herbal and traditional medicinal preparations especially among the Chinese community in
Malaysia to treat colon cancer and it is available without a prescription in most countries. However, in spite of the extensive use of this herb, there is insufficient scientific evidence validating their efficacy and safety. There are possibilities of toxic effect present due to long term use and unpredictable amounts of the substance that produces the therapeutic effect especially hepatotoxic and nephrotoxic effects [5] as the liver and kidney are the two most important organs for detoxification process in the body. Therefore, the aim of this study was to investigate the hepatotoxic and nephrotoxic effects of $R$. decursiva extracts on liver and kidney tissue in male Sprague Dawley rats.

\section{Materials and Methods}

\section{Sample preparation}

The plant (Rhaphidophora decursiva (Roxb.) schott) (Voucher no: SK 2104/13) was collected based on convenience sampling from residential areas of Bercham in the Ipoh city of Perak state, Peninsular Malaysia. Approximately 1 to $2 \mathrm{~kg}$ of the whole plant with stems and leaves were collected. The leaves were separated from the stem and

${ }^{*}$ Corresponding author: Norhaizan Mohd Esa, Department of Nutrition and Dietetics, Faculty of Medicine and Health Sciences, Universiti Putra Malaysia, 43400 Serdang, Selangor, Malaysia; Tel: +60389472427; Fax: +60389426769; E-mail: nhaizan@upm.edu.my

Received January 02, 2014; Accepted January 17, 2014; Published January 19, 2014

Citation: Arsad SS, Esa NM, Hamzah H (2014) Histopathologic Changes in Liver and Kidney Tissues from Male Sprague Dawley Rats Treated with Rhaphidophora Decursiva (Roxb.) Schott Extract. J Cytol Histol S4: 001. doi:10.4172/2157-7099. S4-001

Copyright: (C) 2014 Arsad SS, et al. This is an open-access article distributed under the terms of the Creative Commons Attribution License, which permits unrestricted use, distribution, and reproduction in any medium, provided the original author and source are credited. 
washed thoroughly with distilled water. The washed leaves were cut into small pieces and freeze-drying overnight at $-70^{\circ} \mathrm{C}$. The freeze-dried samples were then stored at $-20^{\circ} \mathrm{C}$ before extracted with methanol.

\section{Sample extraction}

Sample extraction is based on method developed by Othman et al. [6] with slight modifications. Two grams of the freeze-dried samples were weighed and ground into a powder form. The ground freeze-dried samples were extracted with methanol (Merck, German) at a ratio of $0.2 \mathrm{~g}$ of sample to $40 \mathrm{~mL}$ of methanol. The mixture was placed in an orbital shaker (Heidolph Unimax 1010, German) at $200 \mathrm{rpm}$ in room temperature for about 2 hours. Then the mixture was filtered twice with Whatman filter paper no. 4 until clear solution obtained. The unclear solution was centrifuged at $500 \mathrm{rpm}$ for 10 minutes and filtered again using the filter paper. The methanol was removed by a rotary evaporator (BUCHI Rotavapor R-200, Switzerland) and the freeze-dried extract powder was obtained after the solution was freeze-dried in a freezedryer (The VIRTIS Company,USA).

\section{Animals and treatment}

A total of 72 male Sprague Dawley rats weighing approximately 200 to $220 \mathrm{~g}$, supplied by a local supplier (Chenur Supplier, Kuala Lumpur, Malaysia), were used in these studies. The rats were placed in the Animal House at the Faculty of Medicine and Health Sciences, Universiti Putra Malaysia (UPM). The experiment was designed and conducted according to ethical approved by the Animal Care Use Committee (ACUC), Faculty of Medicine and Health Sciences, UPM. The animals were identified uniquely according to their body weight and kept in standard cages of three rats in each cage. All rats were acclimatized at an ambient temperature of $22 \pm 2^{\circ} \mathrm{C}$ with 12 hours light and 12 hours dark cycle for at least five days prior to the start of the experiment. During the acclimatization and experimental periods, the rats were provided drinking water and normal rat chow ad libitum.

The rats were then divided into 4 groups of 6 rats per group for each acute, subacute and subchronic toxicity studies; one control group and three treatment groups for each study. The rats were grouped based on different doses of the plant extract. The doses selected for the 14-day acute toxicity study were 0 (control group), 700, 2800 and $3500 \mathrm{mg} / \mathrm{kg}$ body weight of $R$. decursiva extract according to the OECD guidelines for testing of chemicals [7]. For the 28-day subacute toxicity study and 90-day subchronic toxicity study, the doses selected were 0 (control group), 70, 140 and $210 \mathrm{mg} / \mathrm{kg}$ body weight of the extract [8,9]; lower doses of the plant extract are used in the subchronic toxicity study if lethality is observed in the subacute toxicity study.

\section{Collection of samples for analysis}

At the end of the treatment of the treatment, food was withdrawn from the rats and they were fasted overnight but the animals had free access to water. They were then euthanized through complete exsanguination under ketamine-xylazine anaesthesia and sacrificed. Internal organs including kidney and liver were surgically removed. These were immediately blotted using filter paper to remove traces of blood and then weighed with an analytical balance (Scaltex ${ }^{\otimes}$ SBA51). Thereafter, the tissues were suspended in $10 \%$ formal saline for fixation preparatory to histological processing.

\section{Histopathology analysis}

The fixed liver and kidney tissues were sectioned (5-micron thickness), embedded in paraffin and sections stained with Hematoxylin and Eosin (H\&E). Light microscopic examination of multiple tissue sections from each organ in all groups were performed in all groups and images representative of the typical histological profile were examined. Changes in the experimental histopathologic parameters for liver and kidney tissues were graded as follows: (0) showing no changes, and (1) (2) and (3) indicating mild, moderate and severe changes, respectively, while the grading was determined by percentage as follows: Changes less than $30 \%(<30 \%)$ showing mild changes, changes less than $30 \%-$ $50 \%<30 \%-50 \%)$ indicating moderate changes and changes more than $50 \%(>50 \%)$ showing severe changes $[10,11]$.

\section{Statistical analysis}

The data were represented as mean \pm standard error of mean (S.E.M). The values were considered to be non-parametric, and therefore the data was statistically analyzed by a Kruskal-Willis in order to determine the effects of all groups on each of the experimental parameters, and a Mann-Whitney U Test was used to compare the means of each parameter between the groups. A mean difference was considered significant when $\mathrm{p}<0.05$. Statistical analysis was performed using Statistical Package of Social Science (SPSS) for Window version 20.0 (SPSSInc. Chicago, IL, USA).

\begin{tabular}{|c|c|c|c|c|c|c|}
\hline \multirow{3}{*}{ Organ } & \multirow{3}{*}{$\begin{array}{l}\text { Histopathology scores of } \\
\text { observation (mean) per each } \\
\text { group }\end{array}$} & \multicolumn{5}{|c|}{ Groups } \\
\hline & & \multirow{2}{*}{ A } & \multirow{2}{*}{$\mathrm{B}$} & \multirow{2}{*}{ C } & \multirow{2}{*}{$\mathrm{D}$} & $\begin{array}{c}\text { Kruskal-Wallis Test for global comparison } \\
\text { of organ lesions among groups }\end{array}$ \\
\hline & & & & & & Asymptotic Significant $(p<0.05)$ \\
\hline \multirow{6}{*}{ Liver } & Activated kupffer cells & 0 & 0 & $0.50 \pm 0.22$ & $0.67 \pm 0.21$ & 0.39 \\
\hline & Sinusoidal dilatation & 0 & 0 & $0.33 \pm 0.21$ & $0.67 \pm 0.21$ & 0.39 \\
\hline & Cytoplasmic vacuolation & 0 & 0 & $0.50 \pm 0.22$ & $0.67 \pm 0.21$ & 0.39 \\
\hline & Karyorrlysis & 0 & 0 & 0 & 0 & 1.00 \\
\hline & Karyorrhexis & 0 & 0 & 0 & 0 & 1.00 \\
\hline & Mean score & 0 & 0 & $0.27 \pm 0.13$ & $0.40 \pm 0.13$ & 0.39 \\
\hline \multirow{6}{*}{ Kidney } & Granular cast & 0 & 0 & $0.33 \pm 0.21$ & $0.33 \pm 0.21$ & 0.39 \\
\hline & Cellular cast & 0 & 0 & $0.33 \pm 0.21$ & $0.33 \pm 0.21$ & 0.39 \\
\hline & Protein cast & 0 & 0 & 0 & 0 & 1.00 \\
\hline & Pycnotic cell & 0 & 0 & 0 & 0 & 1.00 \\
\hline & Hydropic degeneration & 0 & 0 & 0 & 0 & 1.00 \\
\hline & Mean score & 0 & 0 & $0.13 \pm 0.08$ & $0.13 \pm 0.08$ & 0.39 \\
\hline
\end{tabular}

Group A: Normal diet (Control); Group B: Normal diet+700 mg/kg extract; Group C: Normal diet + 2100 mg/kg extract; Group D: Normal diet + 3500 mg/kg extract. Table 1: Lesion scores of kidney and liver for all groups analyzed using Kruskal-Wallis test (Acute Toxicity). 
Citation: Arsad SS, Esa NM, Hamzah H (2014) Histopathologic Changes in Liver and Kidney Tissues from Male Sprague Dawley Rats Treated with Rhaphidophora Decursiva (Roxb.) Schott Extract. J Cytol Histol S4: 001. doi:10.4172/2157-7099.S4-001

Page 3 of 6

\begin{tabular}{|c|c|c|c|c|c|c|c|}
\hline \multirow{2}{*}{\multicolumn{2}{|c|}{ Organ }} & $\begin{array}{c}\text { Group A } \\
\text { vs } \\
\text { Group B }\end{array}$ & $\begin{array}{c}\text { Group A } \\
\text { vs } \\
\text { Group C }\end{array}$ & $\begin{array}{c}\text { Group A } \\
\text { vs } \\
\text { Group D }\end{array}$ & $\begin{array}{c}\text { Group B } \\
\text { vs } \\
\text { Group C }\end{array}$ & $\begin{array}{c}\text { Group B } \\
\text { vs } \\
\text { Group D }\end{array}$ & $\begin{array}{c}\text { Group C } \\
\text { vs } \\
\text { Group D }\end{array}$ \\
\hline & & $\begin{array}{l}\text { Asymptotic significant } \\
\qquad(p<0.05)\end{array}$ & $\begin{array}{c}\text { Asymptotic } \\
\text { significant } \\
(p<0.05)\end{array}$ & $\begin{array}{l}\text { Asymptotic significant } \\
(p<0.05)\end{array}$ & $\begin{array}{c}\text { Asymptotic } \\
\text { significant } \\
(p<0.05)\end{array}$ & $\begin{array}{l}\text { Asymptotic significant } \\
(p<0.05)\end{array}$ & $\begin{array}{c}\text { Asymptotic } \\
\text { significant } \\
(p<0.05)\end{array}$ \\
\hline \multirow{6}{*}{ Liver } & Activated kupffer cells & 1.00 & 0.56 & 0.56 & 0.56 & 0.56 & 0.58 \\
\hline & Sinusoidal dilatation & 1.00 & 0.14 & 0.56 & 0.14 & 0.56 & 0.27 \\
\hline & Cytoplasmic vacuolation & 1.00 & 0.56 & 0.56 & 0.56 & 0.56 & 0.58 \\
\hline & Karyorrlysis & 1.00 & 1.00 & 1.00 & 1.00 & 1.00 & 1.00 \\
\hline & Karyorrhexis & 1.00 & 1.00 & 1.00 & 1.00 & 1.00 & 1.00 \\
\hline & Mean score & 1.00 & 0.32 & 0.32 & 0.32 & 0.32 & 0.32 \\
\hline \multirow{6}{*}{ Kidney } & Granular cast & 1.00 & 0.14 & 0.14 & 0.14 & 0.14 & 1.00 \\
\hline & Cellular cast & 1.00 & 0.14 & 0.14 & 0.14 & 0.14 & 1.00 \\
\hline & Protein cast & 1.00 & 1.00 & 0.14 & 1.00 & 0.14 & 0.14 \\
\hline & Pycnotic cell & 1.00 & 1.00 & 0.56 & 1.00 & 0.56 & 0.56 \\
\hline & Hydropic degeneration & 1.00 & 1.00 & 1.00 & 1.00 & 1.00 & 1.00 \\
\hline & Mean score & 1.00 & 0.32 & 0.32 & 0.32 & 0.32 & 0.32 \\
\hline
\end{tabular}

Group A: Normal diet (Control); Group B: Normal diet+700 mg/kg extract; Group C: Normal diet + 2100 mg/kg extract; Group D: Normal diet + 3500 mg/kg extract. Table 2: Results of Mann-Whitney $U$ test for comparisons between groups for lesions in the organs (Acute Toxicity).

\begin{tabular}{|c|c|c|c|c|c|c|}
\hline \multirow{3}{*}{ Organ } & \multirow{3}{*}{$\begin{array}{l}\text { Histopathology scores of } \\
\text { observation (mean) per each group }\end{array}$} & \multicolumn{5}{|c|}{ Groups } \\
\hline & & \multirow{2}{*}{$A$} & \multirow{2}{*}{$\mathrm{B}$} & \multirow{2}{*}{$\mathrm{C}$} & \multirow{2}{*}{$\mathrm{D}$} & $\begin{array}{c}\text { Kruskal-Wallis Test for global comparison } \\
\text { of organ lesions among groups }\end{array}$ \\
\hline & & & & & & Asymptotic Significant $(p<0.05)$ \\
\hline \multirow{6}{*}{ Liver } & Activated kupffer cells & 0 & 0 & $0.17 \pm 0.06$ & $0.17 \pm 0.06$ & 0.39 \\
\hline & Sinusoidal dilatation & 0 & 0 & $0.33 \pm 0.21$ & $0.33 \pm 0.21$ & 0.39 \\
\hline & Cytoplasmic vacuolation & 0 & 0 & $0.33 \pm 0.21$ & $0.33 \pm 0.21$ & 0.39 \\
\hline & Karyorrlysis & 0 & 0 & 0 & 0 & 1.00 \\
\hline & Karyorrhexis & 0 & 0 & 0 & 0 & 1.00 \\
\hline & Mean score & 0 & 0 & $0.17 \pm 0.10$ & $0.17 \pm 0.10$ & 0.39 \\
\hline \multirow{6}{*}{ Kidney } & Granular cast & 0 & 0 & 0 & $0.33 \pm 0.21$ & 0.39 \\
\hline & Cellular cast & 0 & 0 & 0 & $0.50 \pm 0.22$ & 0.39 \\
\hline & Protein cast & 0 & 0 & 0 & 0 & 1.00 \\
\hline & Pycnotic cell & 0 & 0 & $0.17 \pm 0.06$ & $0.33 \pm 0.21$ & 0.39 \\
\hline & Hydropic degeneration & 0 & 0 & 0 & 0 & 1.00 \\
\hline & Mean score & 0 & 0 & $0.03 \pm 0.01$ & $0.23 \pm 0.13$ & 0.39 \\
\hline
\end{tabular}

Group A: Normal diet (Control); Group B: Normal diet+700 mg/kg extract; Group C: Normal diet + 2100 mg/kg extract; Group D: Normal diet + 3500 mg/kg extract.

Table 3: Lesion scores of kidney and liver for all groups analyzed using Kruskal-Wallis test (Subacute Toxicity).

\begin{tabular}{|c|c|c|c|c|c|c|c|}
\hline \multirow{2}{*}{\multicolumn{2}{|c|}{ Organs }} & $\begin{array}{l}\text { Group A } \\
\text { vs } \\
\text { Group B }\end{array}$ & $\begin{array}{c}\text { Group A } \\
\text { vs } \\
\text { Group C }\end{array}$ & $\begin{array}{c}\text { Group A } \\
\text { vs } \\
\text { Group D }\end{array}$ & $\begin{array}{c}\text { Group B } \\
\text { vs } \\
\text { Group C }\end{array}$ & $\begin{array}{c}\text { Group B } \\
\text { vs } \\
\text { Group D }\end{array}$ & $\begin{array}{c}\text { Group C } \\
\text { vs } \\
\text { Group D }\end{array}$ \\
\hline & & $\begin{array}{c}\text { Asymptotic } \\
\text { significant } \\
(p<0.05)\end{array}$ & $\begin{array}{c}\text { Asymptotic } \\
\text { significant } \\
(p<0.05)\end{array}$ & $\begin{array}{c}\text { Asymptotic } \\
\text { significant } \\
(p<0.05)\end{array}$ & $\begin{array}{c}\text { Asymptotic } \\
\text { significant } \\
(p<0.05)\end{array}$ & $\begin{array}{c}\text { Asymptotic } \\
\text { significant } \\
(p<0.05)\end{array}$ & $\begin{array}{c}\text { Asymptotic } \\
\text { significant } \\
(p<0.05)\end{array}$ \\
\hline \multirow{6}{*}{ Liver } & Activated kupffer cells & 1.00 & 0.32 & 0.32 & 0.32 & 0.38 & 1.00 \\
\hline & Sinusoidal dilatation & 1.00 & 0.14 & 0.14 & 0.14 & 0.14 & 1.00 \\
\hline & Cytoplasmic vacuolation & 1.00 & 0.14 & 0.14 & 0.14 & 0.14 & 1.00 \\
\hline & Karyorrlysis & 1.00 & 1.00 & 1.00 & 1.00 & 1.00 & 1.00 \\
\hline & Karyorrhexis & 1.00 & 1.00 & 1.00 & 1.00 & 1.00 & 1.00 \\
\hline & Mean score & 1.00 & 0.32 & 0.32 & 0.32 & 1.00 & 0.32 \\
\hline \multirow{6}{*}{ Kidney } & Granular cast & 1.00 & 1.00 & 0.14 & 1.00 & 0.14 & 0.14 \\
\hline & Cellular cast & 1.00 & 1.00 & 0.06 & 0.06 & 1.00 & 0.06 \\
\hline & Protein cast & 1.00 & 1.00 & 1.00 & 1.00 & 1.00 & 1.00 \\
\hline & Pycnotic cell & 1.00 & 0.32 & 0.14 & 0.32 & 0.14 & 0.52 \\
\hline & Hydropic degeneration & 1.00 & 1.00 & 1.00 & 1.00 & 1.00 & 1.00 \\
\hline & Mean score & 1.00 & 0.32 & 0.32 & 0.32 & 1.00 & 0.32 \\
\hline
\end{tabular}

Group A: Normal diet (Control); Group B: Normal diet+70 mg/kg extract; Group C: Normal diet + $140 \mathrm{mg} / \mathrm{kg}$ extract; Group D: Normal diet + $210 \mathrm{mg} / \mathrm{kg}$ extract.

Table 4: Results of Mann-Whitney $U$ test for comparisons between groups for lesions in the organs (Subacute Toxicity). 


\begin{tabular}{|c|c|c|c|c|c|c|}
\hline \multirow{3}{*}{ Organ } & \multirow{3}{*}{$\begin{array}{l}\text { Histopathology scores of } \\
\text { observation (mean) per each } \\
\text { group }\end{array}$} & \multicolumn{5}{|c|}{ Groups } \\
\hline & & \multirow[t]{2}{*}{ A } & \multirow[t]{2}{*}{ B } & \multirow[t]{2}{*}{ C } & \multirow[t]{2}{*}{$\mathrm{D}$} & $\begin{array}{c}\text { Kruskal-Wallis Test for global comparison } \\
\text { of organ lesions among groups }\end{array}$ \\
\hline & & & & & & Asymptotic Significant $(p<0.05)$ \\
\hline \multirow{6}{*}{ Liver } & Activated kupffer cells & 0 & 0 & 0 & 0 & 0.39 \\
\hline & Sinusoidal dilatation & 0 & 0 & 0 & 0 & 0.39 \\
\hline & Cytoplasmic vacuolation & 0 & 0 & $0.33 \pm 0.21$ & $0.50 \pm 0.22$ & 0.39 \\
\hline & Karyorrlysis & 0 & 0 & 0 & 0 & 1.00 \\
\hline & Karyorrhexis & 0 & 0 & 0 & 0 & 1.00 \\
\hline & Mean score & 0 & 0 & $0.17 \pm 0.04$ & $0.17 \pm 0.04$ & 0.39 \\
\hline \multirow{6}{*}{ Kidney } & Granular cast & 0 & 0 & 0 & $0.17 \pm 0.06$ & 0.39 \\
\hline & Cellular cast & 0 & 0 & 0 & 0 & 1.00 \\
\hline & Protein cast & 0 & 0 & 0 & 0 & 1.00 \\
\hline & Pycnotic cell & 0 & 0 & $0.33 \pm 0.21$ & $0.50 \pm 0.22$ & 0.39 \\
\hline & Hydropic degeneration & 0 & 0 & 0 & 0 & 1.00 \\
\hline & Mean score & 0 & 0 & $0.07 \pm 0.04$ & $0.13 \pm 0.06$ & 0.39 \\
\hline
\end{tabular}

Group A: Normal diet (Control); Group B: Normal diet+70 mg/kg extract; Group C: Normal diet + 140 mg/kg extract; Group D: Normal diet + 210 mg/kg extract.

Table 5: Lesion scores of kidney and liver for all groups analyzed using Kruskal-Wallis test (Subchronic Toxicity).

\begin{tabular}{|c|c|c|c|c|c|c|c|}
\hline \multirow{2}{*}{\multicolumn{2}{|c|}{ Organs }} & $\begin{array}{c}\text { Group A } \\
\text { vs } \\
\text { Group B }\end{array}$ & $\begin{array}{l}\text { Group A } \\
\text { vs } \\
\text { Group C }\end{array}$ & $\begin{array}{l}\text { Group A } \\
\text { vs } \\
\text { Group D }\end{array}$ & $\begin{array}{l}\text { Group B } \\
\text { vs } \\
\text { Group C }\end{array}$ & $\begin{array}{l}\text { Group B } \\
\text { vs } \\
\text { Group D }\end{array}$ & $\begin{array}{l}\text { Group C } \\
\text { vs } \\
\text { Group D }\end{array}$ \\
\hline & & $\begin{array}{c}\text { Asymptotic } \\
\text { significant }(p<0.05)\end{array}$ & $\begin{array}{c}\text { Asymptotic } \\
\text { significant }(p<0.05)\end{array}$ & $\begin{array}{c}\text { Asymptotic } \\
\text { significant }(p<0.05)\end{array}$ & $\begin{array}{c}\text { Asymptotic } \\
\text { significant }(p<0.05)\end{array}$ & $\begin{array}{c}\text { Asymptotic } \\
\text { significant }(p<0.05)\end{array}$ & $\begin{array}{c}\text { Asymptotic } \\
\text { significant }(p<0.05)\end{array}$ \\
\hline \multirow{6}{*}{ Liver } & Activated kupffer cells & 1.00 & 1.00 & 1.00 & 1.00 & 1.00 & 1.00 \\
\hline & Sinusodial widening & 1.00 & 1.00 & 1.00 & 1.00 & 1.00 & 1.00 \\
\hline & Cytoplasmic vacuolation & 1.00 & 0.14 & 0.06 & 0.14 & 0.06 & 0.58 \\
\hline & Karyorrlysis & 1.00 & 1.00 & 1.00 & 1.00 & 1.00 & 1.00 \\
\hline & Karyorrhexis & 1.00 & 1.00 & 1.00 & 1.00 & 1.00 & 1.00 \\
\hline & Mean score & 1.00 & 0.32 & 0.32 & 0.32 & 0.32 & 0.32 \\
\hline \multirow{6}{*}{ Kidney } & Granular cast & 1.00 & 1.00 & 0.32 & 1.00 & 0.32 & 0.32 \\
\hline & Cellular cast & 1.00 & 1.00 & 1.00 & 1.00 & 1.00 & 1.00 \\
\hline & Protein cast & 1.00 & 1.00 & 1.00 & 1.00 & 1.00 & 1.00 \\
\hline & Pycnotic cell & 1.00 & 0.17 & 0.08 & 0.14 & 0.06 & 0.58 \\
\hline & Hydropic degeneration & 1.00 & 1.00 & 1.00 & 1.00 & 1.00 & 1.00 \\
\hline & Mean score & 1.00 & 0.32 & 0.32 & 0.32 & 0.32 & 0.32 \\
\hline
\end{tabular}

Group A: Normal diet (Control); Group B: Normal diet+70 mg/kg extract; Group C: Normal diet + $140 \mathrm{mg} / \mathrm{kg}$ extract; Group D: Normal diet + $210 \mathrm{mg} / \mathrm{kg}$ extract.

Table 6: Results of Mann-Whitney $U$ test for comparisons between groups for lesions in the organs (Subchronic Toxicity).

\section{Results}

\section{Effects of treatment on histology of the liver tissues}

The results of histopathology changes in liver tissues are summarized in Table 1-6. Histological examination of the R. decursiva extract treated samples of liver revealed some abnormal morphology characteristics in group treated with $2100 \mathrm{mg} / \mathrm{kg}$ and $3500 \mathrm{mg} / \mathrm{kg}$ extracts for acute toxicity study, $140 \mathrm{mg} / \mathrm{kg}$ and $210 \mathrm{mg} / \mathrm{kg}$ extracts for both subacute and subchronic toxicity studies ( $\mathrm{p}>0.05$ ). For acute toxicity study, liver tissues in group treated with $2100 \mathrm{mg} / \mathrm{kg}$ and $3500 \mathrm{mg} / \mathrm{kg}$ extracts showed presence of activated kupffer cells, sinusoidal dilatation and cytoplasmic vacuolation as well as group treated with $140 \mathrm{mg} / \mathrm{kg}$ and $210 \mathrm{mg} / \mathrm{kg}$ extracts for both subacute and subchronic toxicity studies except for group treated with $140 \mathrm{mg} / \mathrm{kg}$ extract in subchronic toxicity that just showed the presence of cytoplasmic vacuolation. The changes in the experimental histopathologic parameters for liver were shown in Figure 1.

\section{Effects of treatment on histology of the kidney tissues}

The results of histopathology changes in kidney tissues are summarized in Table 1-6. Similarly, no significant $(p>0.05)$ histopathological changes were observed in the kidneys tissue of the rats for all toxicity studies when compare to the control groups. The presence of granular cast were noticed in group treated with $2100 \mathrm{mg} / \mathrm{kg}$ and $3500 \mathrm{mg} / \mathrm{kg}$ extracts for acute toxicity study, however, cellular cast and protein only occurred in group treated with $3500 \mathrm{mg} / \mathrm{kg}$ extracts. Furthermore, for subacute toxicity studies, only granular and cellular cast can be observed in group treated with $210 \mathrm{mg} / \mathrm{kg}$ extract. Likewise, only granular cast can be seen in group treated with $210 \mathrm{mg} / \mathrm{kg}$ extract for subchronic toxicity. No protein cast was observed in both subacute and subchronic toxicity studies. The changes in the experimental histopathologic parameters for kidney were shown in Figure 2 and 3.

\section{Discussion}

Herbal medicines are widely perceived by the public as being natural, healthful and free from side effects. Most people believe that herbal medicines have no side effects or any potential risks due to their natural origins and are often considered as food supplements and not drugs. Medicinal herbs are usually self-prescribed by the consumers and there is a lack of control and review in terms of dose, manner, and frequency of administration. The chemicals in medicinal herbs may be natural to the plant, but they are not natural to the human body. Any 
compound with therapeutic effect has the potential to be incorrectly prescribed or overdosed. In Malaysia, there is yet a universal regulatory system that ensures the safety of phytopharmaceuticals or herbal products, limiting the availability of safety information with regards to herbs [12]. This study focused on the herbal plant of $R$. decursiva which has extensively been used among the Chinese community in Malaysia for its medicinal properties. The increased use of this plant has resulted in concerns over both the efficacy and safety of the product.

In the present study, histopathology evaluation of $R$. decursiva on the liver and kidney was done after it was fed daily to the male Sprague Dawley rats and indicated that the extract did not adversely affect the morphology of the rats' organs. As indicated earlier, kidney and liver tissues from control group for all toxicity studies showed normal renal and hepatic morphology. In fact, all animals in group treated with 700 $\mathrm{mg} / \mathrm{kg}$ extract for acute toxicity and $70 \mathrm{mg} / \mathrm{kg}$ extract for both subacute and subchronic toxicity presented no morphology changes in kidneys and liver tissues as well. The results were concurrent with the liver function test and kidney function test, which shown normal values in all of the rats from the 14-day acute toxicity, 28-day subacute toxicity study and the 90-day subchronic toxicity study [13].

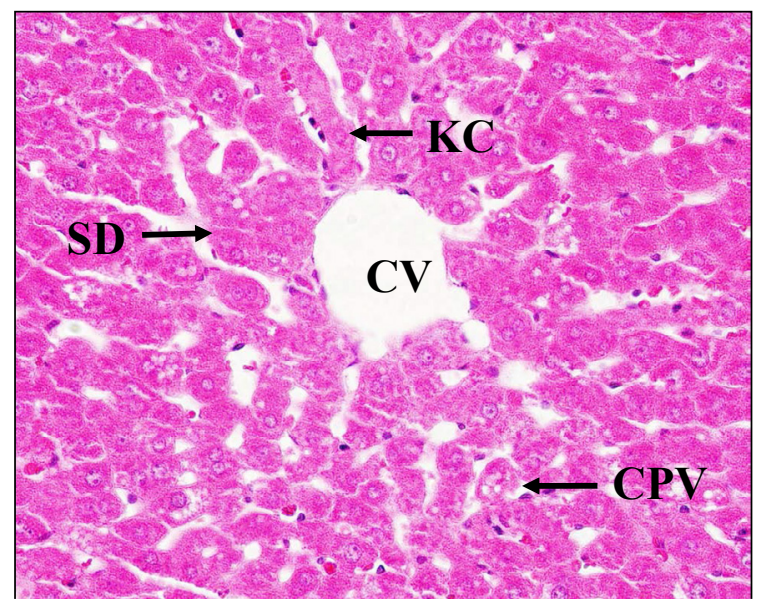

$\mathrm{CPV}=$ Cytoplasmic vacuolation, $\mathrm{CV}=$ Central vein, $\mathrm{KC}=$ Kupffer cell, $\mathrm{SD}=$ Sinusodial dilatation.

Figure 1: Histologic section of liver tissue (section stained with H\&E, x400),

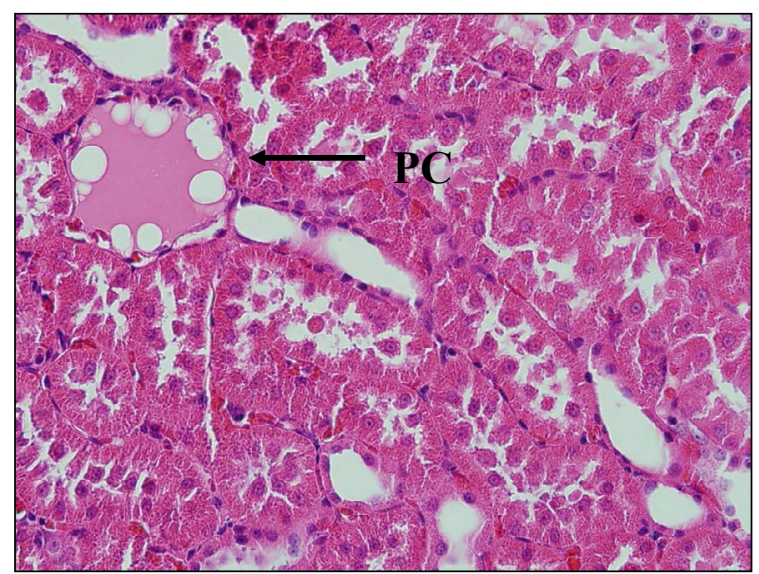

$\mathrm{PC}=$ Protein cast

Figure 2: Histologic section of kidney tissue (section stained with H\&E, X400).

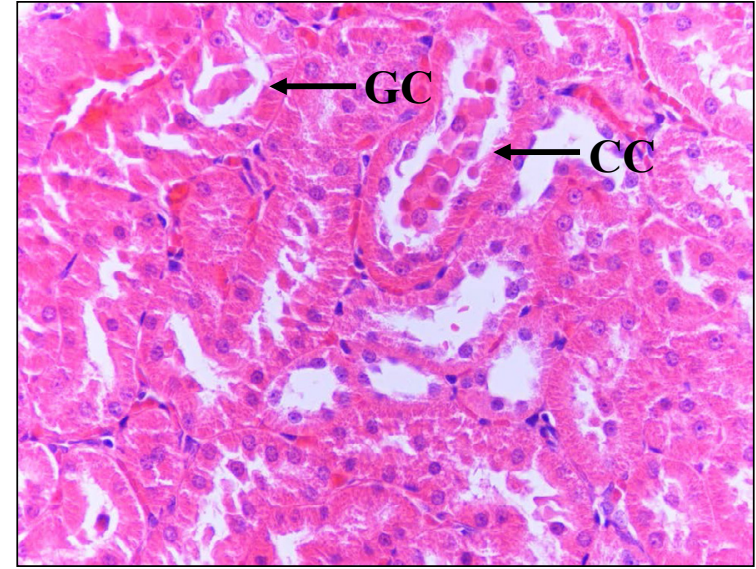

$\mathrm{CC}=$ Cellular cast, $\mathrm{GC}=$ Granular cast.

Figure 3: Histological section of kidney tissue (section stained with H\&E, $\mathrm{x} 400)$.

This finding was comparable to Harizal et al. [14] who used standardized methanolic extract of Mitragyna speciosa (locally known as 'ketum') and reported that the herb revealed some abnormal morphology characteristics in all treatment groups including the lowest dose of treatment $(100 \mathrm{mg} / \mathrm{kg})$ when treated up to 14 days with single dose administration. Almost all the samples treated with Mitragyna specioasa extract showed the presence of activated kupffer cells and enlargement of the nucleus or karyomegaly. The highest dose $(1000 \mathrm{mg} /$ $\mathrm{kg}$ ) of extract induces acute severe hepato-toxicity in rat liver and mild nephrotoxicity in kidney after single dose administration. However, there were no morphological changes in the kidney tissues. Meanwhile, the other study by Salawu et al. [15] using Crossopteryx febrifuga saw inflammatory changes histologically in the liver by infiltration of lymphocytes at portal and central vein of rat treated with at dose level 500 and $1000 \mathrm{mg} / \mathrm{kg}$ and this shows that, the extract exerted deleterious effects on the liver. The liver is capable of regenerating damaged tissue; hence the liver function may not be impaired early following an insult from a toxicant [15].

Degott and Potet [16] reported that sinusoidal dilatation characterized by widening of hepatic capillaries which may involve the entire lobule or predominantly in the central, periportal, or medial area, can be encountered in different situations. It is commonly found in the vicinity of hepatic tumors or heart failure, hepatic venous outflow block, veno-occlusive disease, granulomatous disorders, infectious conditions, or infiltration of sinusoids by various types of benign or malignant cells [17]; and in the clinicopathological entity non-cirrhotic intrahepatic portal hypertension, which consists of various types of architectural alterations. These alterations include nodular regenerative hyperplasia, perisinusoidal fibrosis, hepatoportal sclerosis, or incomplete septal cirrhosis [18]; have been related to several causal factors, including xenobiotics (thorium salts, arsenicals, vinyl chloride, vitamin A, or azathioprine) and thrombophilia [18]. All of these factors have been postulated to act by inducing portal or sinusoidal obstruction.

Based on the results on kidney tissues, the observations seem to suggest that certain medicinal plants might have renal protective ability to prevent kidney dysfunction by accelerating regeneration. There are two possible effects of various herbs on kidneys, harmful or beneficial. Harmful effects include: polyuria, causing dehydration, acute renal failure, chronic renal insufficiency and stone formation. 
Citation: Arsad SS, Esa NM, Hamzah H (2014) Histopathologic Changes in Liver and Kidney Tissues from Male Sprague Dawley Rats Treated with Rhaphidophora Decursiva (Roxb.) Schott Extract. J Cytol Histol S4: 001. doi:10.4172/2157-7099.S4-001

Page 6 of 6

Possible beneficial effects include: dieresis, protection of the kidney from nephrotoxic agents, prevention or amelioration of renal lithiasis, and amelioration of kidney failure [19].

A study conducted by Alade et al. [20] with B. monandra leaf extract revealed the histology of kidney observed with focal proximal tubular epithelial necrosis and a variation in the lung between the controls and treated rat at the dose of $4 \mathrm{~g} / \mathrm{kg}$. Another study conducted by Akanmu et al. [21] on C. fistula pods extract revealed slight differences in the histology of kidney of rats treated with extract at the dose $1000 \mathrm{mg} / \mathrm{kg}$ where some of the glomeruli and the proximal tubules was observed to widen without any injury compared to the control. Based on the histopatholgy results, this showed that the treatment of R.decursiva extracts did not show any toxicological significance as no significant histopathological changes were observed in the kidney and liver tissues for all toxicity studies.

\section{Acknowledgement}

This research was financially supported by a RUGS grant 04-02-11-1383RU from the Universiti Putra Malaysia.

\section{References}

1. Wiseman N (2004) Designations of Medicines. Evid Based Complement Alternat Med 1: 327-329.

2. Desai AK, Grossberg GT (2003) Herbals and botanicals in geriatric psychiatry Am J Geriatr Psychiatry 11: 498-506.

3. McCann J (2003) Herbal Medicine Handbook 2ndedn. Philadelphia: Lippincott.

4. Joshi BS, Kaul PN (2001) Alternative medicine: Herbal drugs and their critical appraisal-Part I. Prog Drug Res 56: 1-76.

5. Saad B, Azaizeh H, Abu-Hijleh G, Said O (2006) Safety of traditional arab herbal medicine. Evid Based Complement Alternat Med 3: 433-439.

6. Othman A, Ismail A, Ghani AN, Adenan I (2007) Antioxidant capacity and phenolic content of cocoa beans. Food Chem 100: 1523-1530.

7. OECD (2001). OECD Guideline for Testing of Chemicals (TG 423). Acute Oral Toxicity-Fixed Dose Procedure. OECD/OEDC.

8. OECD (1998) OECD Guideline for Testing of Chemicals (TG 408). Repeated Dose 90-day Oral Toxicity Study in Rodents. OECD/OEDC.
9. OECD (2008). OECD Guideline for Testing of Chemicals (TG 407). Repeated Dose 28-Day Oral Toxicity Study in Rodents. OECD/OEDC.

10. Jain A, Soni M, Deb L, Jain A, Rout SP, et al. (2008) Antioxidant and hepatoprotective activity of ethanolic and aqueous extracts of Momordica dioica Roxb. leaves. J Ethnopharmacol 115: 61-66.

11. Tan PV, Mezui C, Enow-Orock G, Njikam N, Dimo T, et al. (2008) Teratogenic effects, acute and sub chronic toxicity of the leaf aqueous extract of Ocimum suave Wild (Lamiaceae) in rats. J Ethnopharmacol 115: 232-237.

12. Mohammed MAM (2006) Effect of Morinda citrifolia (linn.) $n$ phase $i$ and ii drug metabolism and its molecular mechanism elucidation in rat liver. Master of Science Thesis, Universiti Sains Malaysia. Malaysia.

13. Arsad SS, Mohd Esa N, Hamzah H, Othman F (2013) Evaluation of acute, subacute and subchronic oral toxicity of Rhaphidophora decursiva (Roxb.) Schott extract in male Sprague Dawley rats. J Med Plant Res 7: 3030-3040.

14. Harizal SN, Mansor SM, Hasnan J, Tharakan JK, Abdullah J (2010) Acute toxicity study of the standardized methanolic extract of Mitragyna speciosa Korth in rodent. J Ethnopharmacol 131: 404-409.

15. Salawu OA, Chindo BA, Tijani AY, Obidike IC, Salawu TA, et al. (2009) Acute and sub-acute toxicological evaluation of the methanolic stem bark extract of Crossopteryx febrifuga in rats. Afr J Pharm Pharacol 3: 621-626.

16. Degott C, Potet F (1984) [Peliosis hepatis and sinusoidal dilatation]. Arch Anat Cytol Pathol 32: 296-300.

17. Laffón A, Moreno A, Gutierrez-Bucero A, Ossorio C, Sabando P, et al. (1989) Hepatic sinusoidal dilatation in rheumatoid arthritis. J Clin Gastroenterol 11: 653-657.

18. Hillaire S, Bonte E, Denninger MH, Casadevall N, Cadranel JF, et al. (2002) Idiopathic non-cirrhotic intrahepatic portal hypertension in the West: a reevaluation in 28 patients. Gut 51: 275-280.

19. Myhre MJ (2000) Herbal remedies, nephropathies, and renal disease. Nephro Nurs J 27: 473-478.

20. Alade GO, Akanmu MA Obuotor EM, Osasan SA Omobuwajo OR, et al. (2009) Acute and oral subacute toxicity of methanolic extract of Bauhinia monandra leaf in rats. Afr J Pharm Pharacol 3: 354-358.

21. Akanmu MA, Iwalewa EO, Elujoba AA, Adelusola KA (2004) Toxicity potentials of Cassia fistula fruits as laxative with reference to senna. Afr J Biomed Res 7: 23-26.
This article was originally published in a special issue, Histology and Histopathology handled by Editor(s). Borislav A. Alexiev, University of Maryland Medical Center, USA 